\title{
PH domain of BCR provides colocalization of full-length BCR with centrosome together with cortactin to facilitate actin-organizing function
}

\author{
D. S. Gurianov, S. V. Antonenko, G. D. Telegeev \\ Institute of Molecular Biology and Genetics, NAS of Ukraine \\ 150, Akademika Zabolotnoho Str., Kyiv, Ukraine, 03143 \\ dmitriy.gurianov@gmail.com
}

Chromosomal translocation between 9 and 22 chromosomes leads to the fusion of $b c r$ and $a b l$ genes. Because of different breakpoints in $b c r$ gene three forms of chimeric BCR-ABL proteins exist $-\mathrm{p} 230$, p210, and p190. BCR-ABL ${ }^{\mathrm{p} 190}$ lacks Pleckstrin homology (PH) domain of BCR and is associated with acute lymphoblastic leukaemia. In contrast, BCR-ABL ${ }^{\mathrm{p} 210}$ has $\mathrm{PH}$ domain and occurs during chronic myeloblastic leukaemia. BCR-ABL can bind to centrosomes, which function as a regulating center of cell division and spindle formation during mitosis. Cortactin, the main function of which is actin branching, was previously identified by massspectrometry as one of the potential partners interacting with the PH domain of BCR. Aim. To determine whether BCR and cortactin colocalize with centrosomes and to study a possible role of PH domain in such colocalization. Methods. Mammalian cell culturing, immunofluorescence analysis, fluorescence microscopy of live cells. Results. In the present work we show that both full-length BCR protein and $\mathrm{PH}$ domain colocalize with centrosome together with cortactin in live HEK293T cells. We also demonstrate that BCR colocalizes with $\gamma$-tubulin and the points of actin branching in fixed K562 cells. Using anti-ABL and anti-BCR antibodies we also show that colocalization with the actin branching center is typical for BCR-ABL and $\mathrm{BCR}$, but not for $\mathrm{ABL}$ alone. Conclusions. $\mathrm{PH}$ domain of $\mathrm{BCR}$ is required for colocalization of $\mathrm{BCR}$ or BCR-ABL with centrosome. Together with cortactin, BCR-ABL can affect centrosome function through deregulation of actin branching or abnormal phosphorylation, which can be a matter of further research.

Ke y w o r d s: BCR-ABL, centrosome, cortactin, CML.

\section{Introduction}

The chromosomal translocation between 9 and 22 chromosomes leads to generation of
Philadelphia chromosome [1] and promotes the development of different types of myelo-

(C) 2021 D. S. Gurianov et al.; Published by the Institute of Molecular Biology and Genetics, NAS of Ukraine on behalf of Biopolymers and Cell. This is an Open Access article distributed under the terms of the Creative Commons Attribution License (http://creativecommons.org/licenses/by/4.0/), which permits unrestricted reuse, distribution, and reproduction in any medium, provided the original work is properly cited 
proliferative disorders. The phenotype of myeloproliferative disorder is usually determined by the type of chimeric protein generated as a result of translocation and fusion of $b c r$ and $a b l$ genes. Acute lymphoblastic leukaemia is associated with BCR-ABL ${ }^{190}$ protein, chronic myelogenous leukaemia - with BCR$\mathrm{ABL}^{\mathrm{p} 210}$ protein, chronic neutrophilic leukaemia - with BCR-ABL ${ }^{\mathrm{p} 230}$ protein. These three proteins differ only in the presence or absence of certain domains of BCR, whereas ABL part remains constant in all three types. We previously identified that $\mathrm{PH}$ domain of BCR potentially interacts with 23 proteins of K562 cell line, which was originally derived from CML patient [2]. We focused on the cortactin as a promising candidate for interaction with $\mathrm{PH}$ domain because cortactin is frequently involved in cancer progression. Primarily its role in cancer progression is caused by abnormalities in actin regulation leading to increased invasiveness and altered adhesion [3]. This, however, is more common for solid tumors with different subpopulations of cancer cells [4-8]. The role of CTTN in progression of blood cancer, which is a result of clonal expansion of the most proliferatively active cells, is still poorly understood. In one of our previous work we discovered that CTTN and PH domain of BCR are colocalized near the cell nucleus [9]. However, we could not identify the structure they were attached to. It is known that centrosome is a microtubule-organizing center that is located near the cell nucleus and regulate the important processes such as the formation of mitotic spindle during cell division [10]. Moreover, it is known that centrosomes are actin-organizing unit as well [11]. The previous studies showed that leukemic cells disrupted the centrosome function and that the BCR-ABL protein was among the centrosome-associated proteins as it was demonstrated by co-immunoprecipitation [12]. Another study indicates that [the] phosphorylated form of CTTN is associated with centrosome [13]. In this study we aim to determine whether the full-length $\mathrm{BCR}$ and $\mathrm{PH}$ domain of BCR colocalize with centrosomes as well as whether CTTN is involved in this process.

\section{Materials and Methods}

Plasmid vectors and genetic constructs. Vector EGFP-PH was created previously in our lab [2]. CTTN sequence was amplified using pOTB7-CTTN vector with CTTN-F (5'ATGTGGAAAGCTTCAGCAGG) and CTTN-R (5'AGCTCCACATAGTTGGCTGG) primers and cloned into pBluescriptSKII $(+)$ vector on EcoRV site. Further, CDS of cortactin nucleotide sequence was subcloned into pmTagRFP-N1 (Michael Davidson, Florida State University) on BamHI and SalI sites. Plasmids were isolated from the transformed overnight culture of E.coli NEB Turbo cells grown on selective antibiotic by the alkaline lysis method [14]. To obtain transfection-grade plasmid DNA, purification was done by $\mathrm{CaCl} 2$ precipitation followed by $\mathrm{NaCl} / \mathrm{PEG} 6000$ precipitation [15].

Cultivation of HEK293T and K562 cells. HEK293T and K562 cells were obtained from cell line bank of EMBL, Heidelberg. HEK293T cells were grown in DMEM media with L-glutamine containing $10 \%$ fetal bovine serum, $100 \mu \mathrm{g} / \mathrm{ml}$ streptomycin, $10000 \mathrm{U}$ penicillin at $+37{ }^{\circ} \mathrm{C}, 5 \% \mathrm{CO}_{2}$ and $95 \%$ relative humidity. K562 cells were grown in RPMI1640 media with L-glutamine containing $10 \%$ 
fetal bovine serum, $100 \mu \mathrm{g} / \mathrm{ml}$ streptomycin, $10000 \mathrm{U}$ penicillin at $+37{ }^{\circ} \mathrm{C}, 5 \% \mathrm{CO}_{2}$ and $95 \%$ relative humidity. The cell lines were tested negative for mycoplasma before performing experiments.

Antibodies and dyes. Rabbit primary polyclonal anti-BCR antibody (Abclonal, AA0068), mouse primary monoclonal anti- $\gamma$-tubulin antibody (Thermo Fisher Scientific, MA119421), mouse primary anti-ABL antibody (Calbiochem, OP20), anti-mouse Alexa-555 conjugated secondary antibodies (Abclonal, AS057), anti-rabbit secondary Alexa-647 conjugated secondary antibodies (Abclonal, AS060), FITC-phalloidin (Sigma-Aldrich, P5282), DAPI (Sigma-Aldrich, D9542), SiRtubulin (Spirochrome, SC002).

Fixation and Staining. Before fixation, growth media was carefully aspirated from cells. After that the cells were fixed in $4 \%$ paraformaldehyde (Sigma-Aldrich, 158127) in PBS for $15 \mathrm{~min}$ at room temperature. Following fixation, the cells were washed thrice with PBS and permeabilized in $0.1 \%$ Triton X-100 (Serva) in PBS for 10 minutes at room temperature. Next, cells were washed thrice with PBS, and blocked in $1 \%$ Bovine Serum Albumine (Sigma-Aldrich, 05470) in PBS for 1 hour at room temperature. Blocking solution was discarded and corresponding solution of primary antibodies was added to the cells and incubated overnight at $+4{ }^{\circ} \mathrm{C}$. Following incubation, cells were washed thrice with PBS and corresponding solution of secondary antibodies was added and incubated for 1 hour at room temperature. After incubation with secondary antibodies the cells were washed thrice with PBS and mounted on microslides with Mowiol 4-88 (Sigma-Aldrich, 81381) hardening me- dium [16] containing $2.5 \%$ DABCO (SigmaAldrich, D27802) as antifade reagent. Cells were ready for imaging 24 hours after mounting. For fixation and staining of K562 cells, the modified protocol was used that involves centrifugation for discarding the supernatant.

Fluorescence Microscopy. For fixed and live cell imaging we have used Carl Zeiss LSM 510 Meta confocal microscope with $100 x$ oil objective and 1.4 numerical aperture. For excitation of ECFP we used $405 \mathrm{~nm}$ laser line, for excitation of EGFP $488 \mathrm{~nm}$ laser line was used, for excitation of mTagRFP and SiRtubulin/Alexa-647-532 $\mathrm{nm}$ and $633 \mathrm{~nm}$ laser lines, respectively. The line-by-line sequential acquisition mode was used for live imaging. The laser intensity and detection channels were adjusted to avoid cross-excitation and spectral bleedthrough. Effective pixel and voxel sizes were calculated according to Nyquist criteria $[17,18]$. Live cell imaging was done at $+37^{\circ} \mathrm{C}$ and $5 \% \mathrm{CO} 2$ in custom designed $\mathrm{CNC}$ machined anodized aluminum slides with pads designed to fit $18 * 18 \mathrm{~mm}$ glass coverslips. Briefly, slides are of size of standard glass microslides and contain rectangular hole with pads. Pads are covered with coverslips, the growth medium is placed between two slides. Coverslips were sealed using food-grade silicon grease.

Image processing and analysis. Image analysis and processing were done in Fiji software [19]. Colocalization analysis was performed in JaCOP plugin [20] using Manders coefficients [21]. Before analysis, the Gaussian deblur filter with radius of 1 pixel was applied to the image. Background was measured by line profiler and subtracted from the images if necessary. The images were then deconvolved 
with Deconvolution Lab 2 plugin [22] using Richardson-Lucy Total Variation algorithm [23] with theoretical PSF generated by PSF Generator plugin [24]. The number of iterations for deconvolution ranged from 5 to 20 and was chosen empirically for the best structure preservation and absence of artifacts. Generation of final montage of image sets was done using Fiji EzFig plugin [25].

\section{Results and Discussion}

Disruption of centrosome function often leads to the development of different types of cancer [26]. These abnormalities may be caused by alteration in mitotic spindle formation and consequent deregulation of cell cycle and division [27]. Centrosome abberations are the well known feature of BCR-ABL-positive chronic myelogenous leukaemia [28]. It is still undetermined, whether it was a direct action of chimeric protein or cascade of regulatory events indirectly initiated by it. Moreover, centrosome also plays a role as actin organizing center, which promotes actin nucleation by WASH and Arp2/3 [11]. Cortactin in its phosphorylated form is able to bind to centrosome [13]. The cortactin-mediated actin branching typically involves Arp $2 / 3$ complex and dynamin [29-32]. Dynamin binds to membrane by its $\mathrm{PH}$ domain and provides coordinated cytoskeleton-membrane rearrangements [33]. We suggest that $\mathrm{PH}$ domain of BCR may have the similar function because it possesses strong affinity to phoshotidyl-inositol-phosphates [2]. In centrosomes cortactin mediates actin scaffold for separation of centrosomes during mitosis [13]. Because it is one of the potential interaction partner of $\mathrm{PH}$ domain of $\mathrm{BCR}$ it is interesting to determine whether this protein is able to colocalize with centrosome together with BCR-ABL. Here we show that indeed cortactin colocalizes with centrosomes both with PH domain of BCR and with fulllength BCR in live HEK293T cells. To calculate the percentage of cooccurrence between two proteins we have taken Manders coefficient equal to 1 as $100 \%$ colocalization. In HEK293T live cells $40.5 \%$ of tubulin overlapped CTTN and $32.6 \%$ of CTTN overlapped tubulin for colocalization analysis between SiR-Tubulin and mTagRFP-N1-CTTN, $63.7 \%$ of tubulin overlapped BCR and $27.6 \%$ of BCR overlapped tubulin for colocalization analysis between SiR-Tubulin and ECFPBCR, $87.8 \%$ of CTTN overlapped BCR and $62 \%$ of BCR overlapped CTTN for mTagRFPN1-CTTN and ECFP-BCR (Fig. 1, $\mathrm{n}=3$ ). Colocalization analysis of EGFP-PH and mTagRFP-N1-CTTN showed that $34.2 \%$ of PH domain of BCR was also found to colocalize with cortactin and $62.6 \%$ of cortactin overlapped PH domain, it was also found that cortactin and PH domain overlapped centrosomes resulting in $12.9 \%$ of $\mathrm{PH}$ domain overlapping tubulin and $54.1 \%$ of cortactin overlapping tubulin, tubulin overlapped $\mathrm{PH}$ domain and cortactin in fraction of $35.4 \%$ and $60.1 \%$ respectively (Fig. 2, n=3). SiR-tubulin is a stain for live cell imaging of tubulin that can detect both filamentous tubulin and centrosomal region. Filamentous tubulin consists of $\alpha$ - and $\beta$-tubulin subunits [34] whereas centrosome consists mainly of $\gamma$-tubulin $[35,36]$. We have used anti- $\gamma$-tubulin antibodies to check whether BCR is able to colocalize with centrosomes in fixed K562 cells. We detected that $65.6 \%$ of BCR overlapped $\gamma$-tubulin and 49.6 $\%$ of $\gamma$-tubulin overlapped BCR. We also found 


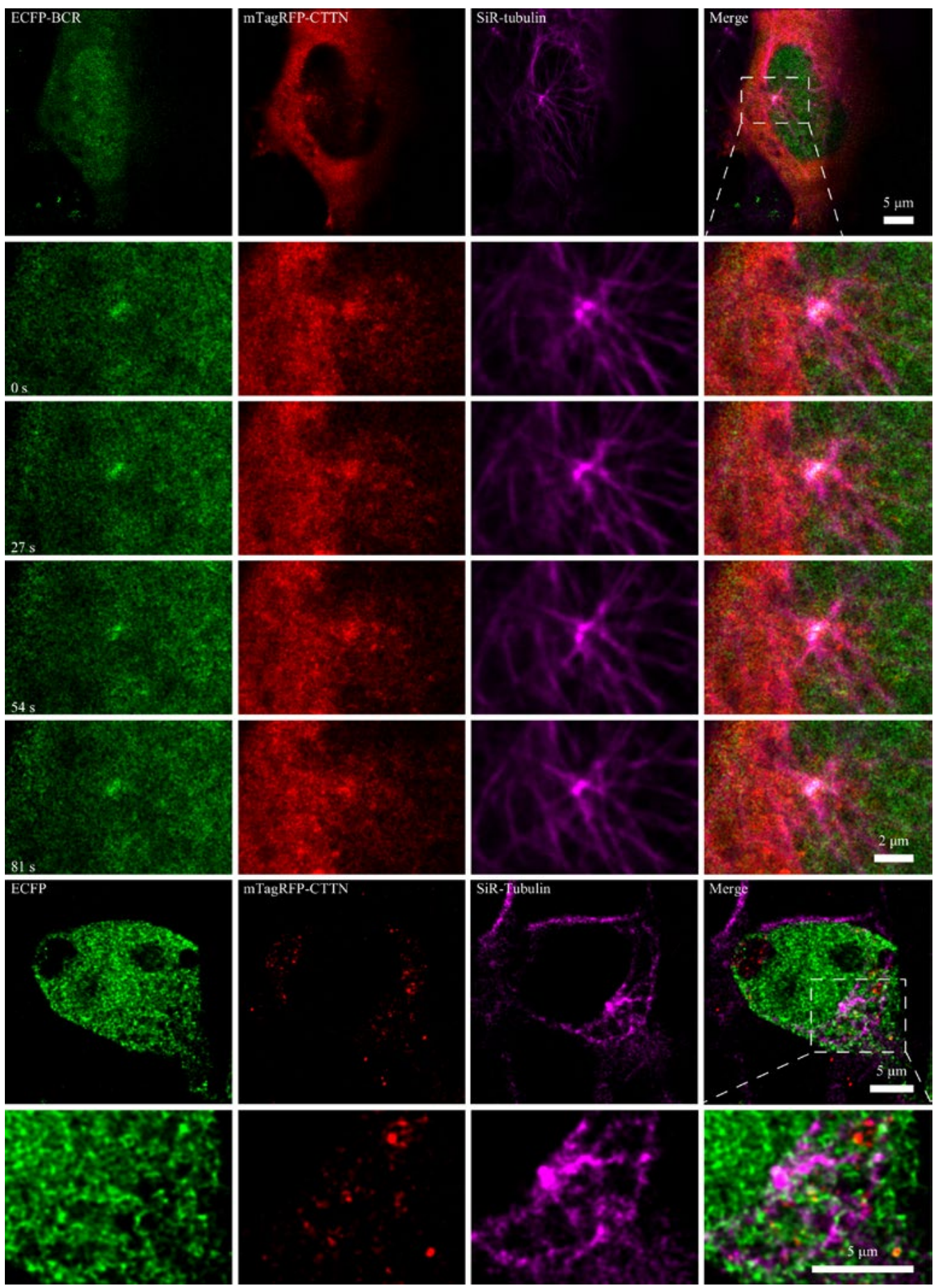

Fig. 1. Live cell imaging of HEK293T cells transfected with pECFP-BCR, ECFP, pmTagRFP-N1-CTTN vectors and stained with SiR-Tubulin. 


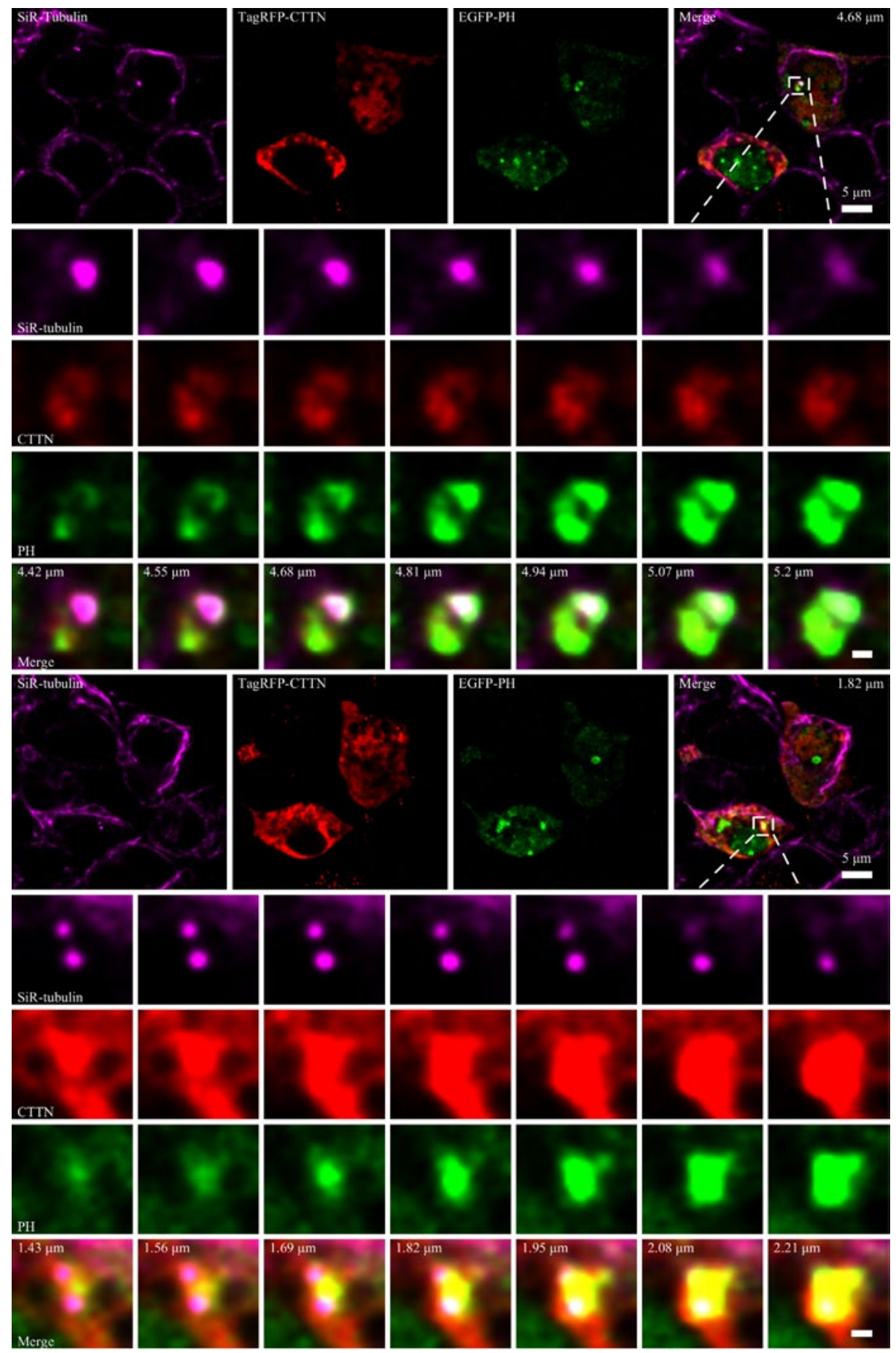

Fig. 2. Live cell confocal image of two projections of HEK293T cells transfected with EGFP-PH, pmTagRFP-N1CTTN and stained with SiR-Tubulin. Scale bar on enlarged regions of interest indicates $500 \mathrm{~nm}$. 
that $83.2 \%$ of BCR and $73.8 \%$ of $\gamma$-tubulin overlapped actin, $36.6 \%$ of actin overlapped BCR and $38 \%$ of actin overlapped $\gamma$-tubulin (Fig. 3, n=3). Colocalization between BCR and $\gamma$-tubulin occurred in the points of actin branching. Such colocalization indicates a potential role of BCR-ABL in actin branching center. We may suggest that overlapping of BCR-ABL with cortactin in the centrosomal region may initiate actin branching not synchronized with the cell division cycle. It is also possible that other centrosomal proteins may be affected by the constant tyrosine-kinase activity of BCR-ABL. We also detected that the fusion protein $\mathrm{BCR} / \mathrm{ABL}$ appears at the points of actin branching by staining fixed K562 cells with anti-BCR and anti-ABL antibodies and FITC-phalloidin. We have found that $75.6 \%$ of BCR overlapped $\mathrm{ABL}$ and $67.7 \%$ of ABL overlapped BCR, $87.6 \%$ of
Table 1. Overlap analysis between different pairs of proteins using Manders coefficents.

\begin{tabular}{l|c|c}
\hline \multicolumn{1}{c|}{ Protein pair } & Manders M1 & Manders M2 \\
\hline EGFP-PH/SiR-tubulin & 0.129 & 0.354 \\
\hline EGFP-PH/mTagRFP-CTTN & 0.342 & 0.626 \\
\hline $\begin{array}{l}\text { mTagRFP-CTTN/SiR- } \\
\text { tubulin (Fig. 2) }\end{array}$ & 0.541 & 0.601 \\
\hline ECFP-BCR/mTagRFP-CTTN & 0.62 & 0.878 \\
\hline ECFP-BCR/SiR-tubulin & 0.276 & 0.637 \\
\hline $\begin{array}{l}\text { mTagRFP-CTTN/SiR- } \\
\text { tubulin (Fig. 1) }\end{array}$ & 0.326 & 0.405 \\
\hline anti-BCR/anti- $\gamma$-tubulin & 0.656 & 0.496 \\
\hline $\begin{array}{l}\text { anti-BCR/actin (FITC- } \\
\text { phalloidin) }\end{array}$ & 0.832 & 0.366 \\
\hline $\begin{array}{l}\text { Actin (FITC-phalloidin)/anti- } \\
\gamma \text {-tubulin }\end{array}$ & 0.38 & 0.738 \\
\hline anti-BCR/anti-ABL & 0.759 & 0.677 \\
\hline $\begin{array}{l}\text { anti-BCR/actin (FITC- } \\
\text { phalloidin) }\end{array}$ & 0.876 & 0.245 \\
\hline $\begin{array}{l}\text { anti-ABL/actin (FITC- } \\
\text { phalloidin) }\end{array}$ & 0.893 & 0.307 \\
\hline $\begin{array}{l}\text { ECFP/mTagRFP-CTTN } \\
\text { ECFP/SiR-tubulin }\end{array}$ & 0.008 & 0.292 \\
\hline
\end{tabular}
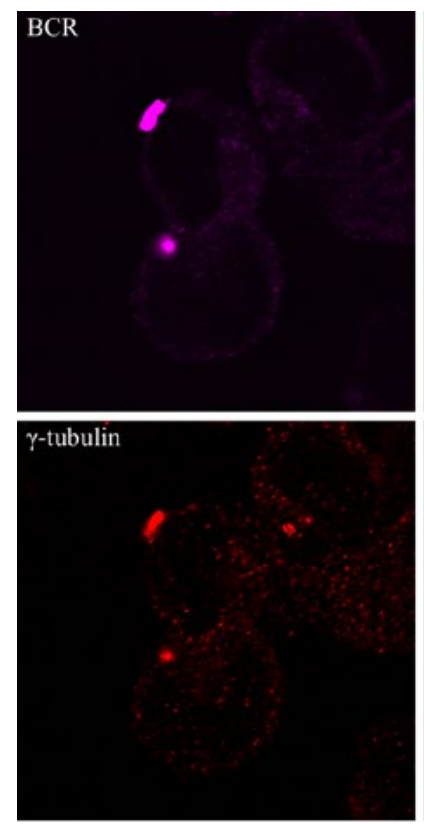
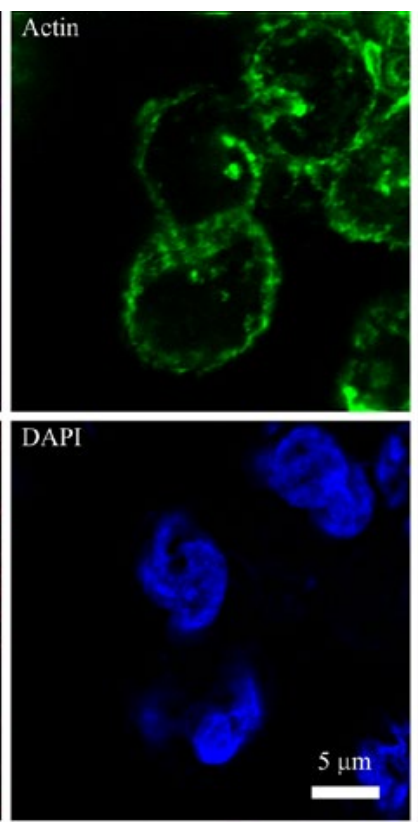

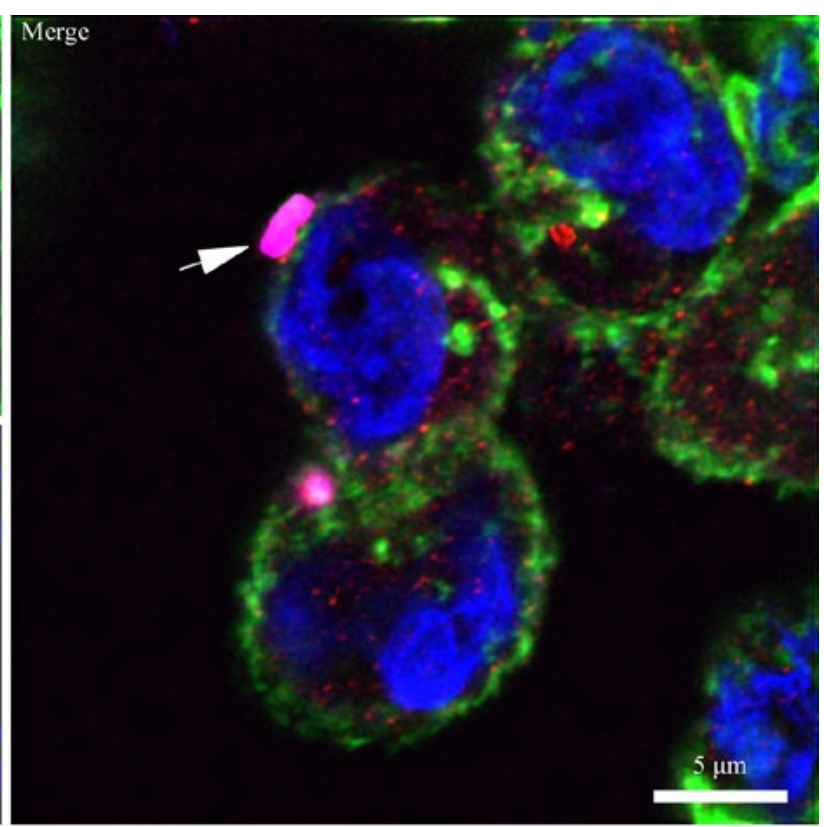

Fig. 3. Confocal image of fixed K562 cells stained with anti-BCR, anti- $\gamma$-tubulin, phalloidin-FITC and DAPI. Negative controls depict secondary antibodies without corresponding target primary antibodies. 
BCR and $89.3 \%$ of ABL overlapped with $n=5$ ). Overlap analysis between different proactin, $24.5 \%$ actin overlapped with BCR and teins and empty ECFP as the control sample $30.7 \%$ of actin overlapped with ABL (Fig. 4, (Fig. 1, $\mathrm{n}=3$ ) is summarized in Table 1.

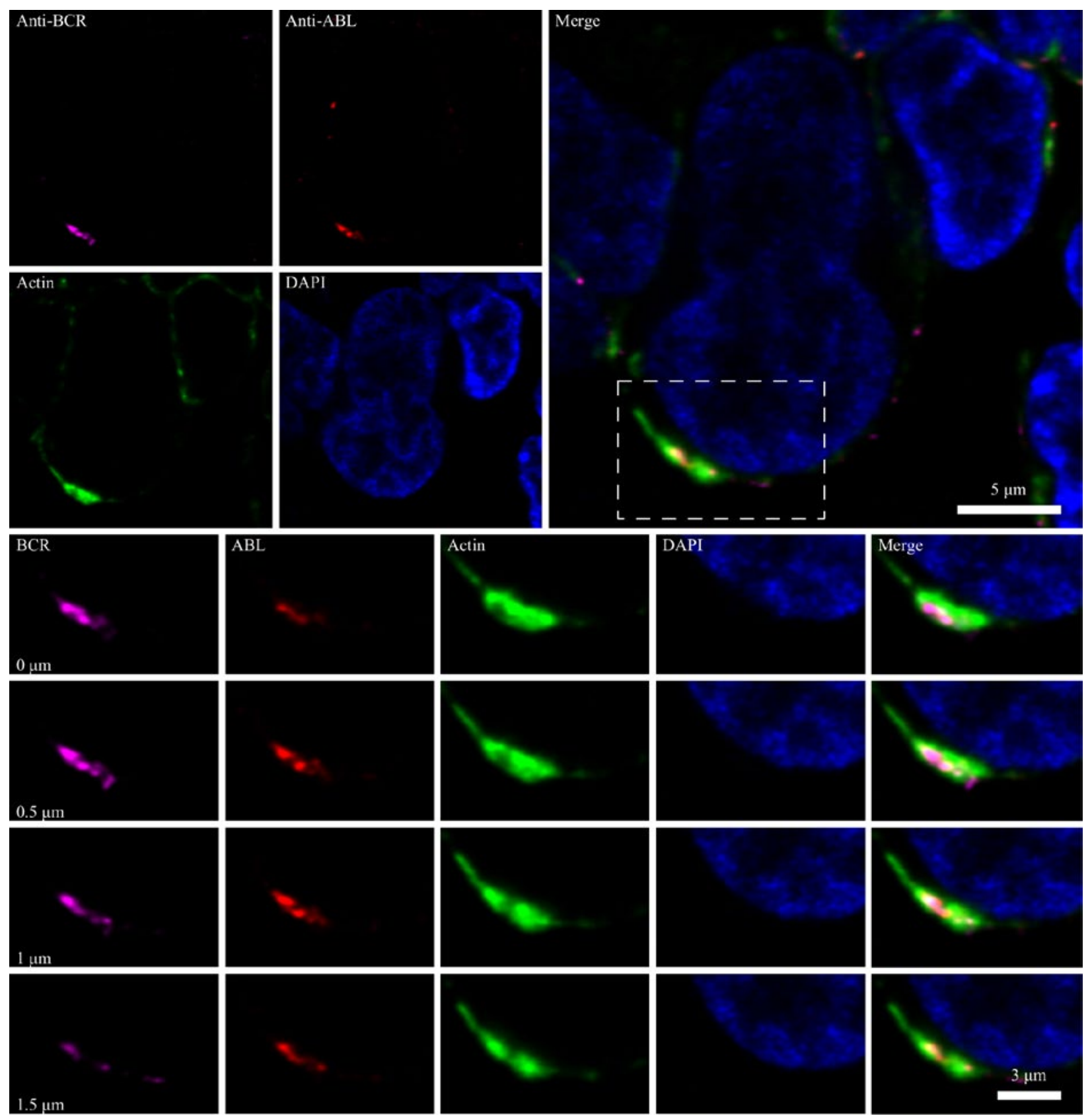

Fig. 4. Confocal image of fixed K562 cells stained with FITC-phalloidin, anti-BCR and anti-ABL antibodies, and DAPI. 
Interestingly, ABL protein alone does not colocalize with centrosome without BCR, as we may see using anti-ABL and anti-BCR antibodies, despite the fact that it has actinbinding domain. Our results show that cortactin and BCR-ABL may be involved in centrosomal abberations possibly by affecting its actin-organizing function. Further study should include creating deletion mutants of BCR that lack $\mathrm{PH}$ domain and determining whether this will affect colocalization with centrosome and cortactin. The results may identify cortactin as one of the potential therapeutic targets for treatment of CML.

\section{Funding}

This work was supported by the I-Next grant (project id: 8230) in the framework of Horizon 2020 program.

\section{REFERENCES}

1. Hecht F, Morgan R, Schrier SL, Adams J, Sandberg $A A$. The Philadelphia $(\mathrm{Ph})$ chromosome in leukemia. I. A new mechanism due to interstitial deletion and insertion in chronic myelocytic leukemia. Cancer Genet Cytogenet. 1985;14(1-2):3-10.

2. Miroshnychenko D, Dubrovska A, Maliuta S, Telegeev $G$, Aspenström P. Novel role of pleckstrin homology domain of the Bcr-Abl protein: analysis of protein-protein and protein-lipid interactions. Exp Cell Res. 2010;316(4):530-42.

3. Weaver AM. Cortactin in tumor invasiveness. Cancer Lett. 2008;265(2):157-66.

4. Hirakawa H, Shibata K, Nakayama T. Localization of cortactin is associated with colorectal cancer development. Int J Oncol. 2009;35(6):1271-6.

5. Rothschild BL, Shim AH, Ammer AG, Kelley LC, Irby $K B$, Head JA, Chen L, Varella-Garcia $M$, Sacks $P G$, Frederick B, Raben D, Weed SA. Cortactin overexpression regulates actin-related protein $2 / 3$ complex activity, motility, and invasion in car- cinomas with chromosome 11q13 amplification. Cancer Res. 2006;66(16):8017-25.

6. Patel AS, Schechter GL, Wasilenko WJ, Somers KD. Overexpression of EMS1/cortactin in NIH3T3 fibroblasts causes increased cell motility and invasion in vitro. Oncogene. 1998;16(25):3227-32.

7. Ambrosio EP, Rosa FE, Domingues MA, Villacis RA, Coudry Rde A, Tagliarini JV, Soares FA, Kowalski LP, Rogatto $S R$. Cortactin is associated with perineural invasion in the deep invasive front area of laryngeal carcinomas. Hum Pathol. 2011;42(9):1221-9.

8. Bertier L, Boucherie C, Zwaenepoel O, Vanloo B, Van Troys M, Van Audenhove I, Gettemans J. Inhibitory cortactin nanobodies delineate the role of NTA- and SH3-domain-specific functions during invadopodium formation and cancer cell invasion. FASEB J. 2017;31(6):2460-2476.

9. Gurianov DS, Antonenko SV, Telegeev GD. Colocalization of cortactin and $\mathrm{PH}$ domain of BCR in HEK293T cells and its potential role in cell signaling. Biopolym Cell. 2016; 32(1): 26-33.

10. Conduit PT, Wainman A, Raff JW. Centrosome function and assembly in animal cells. Nat Rev Mol Cell Biol. 2015;16(10):611-24.

11. Farina F, Gaillard J, Guérin C, Couté Y, Sillibourne J, Blanchoin L, Théry M. The centrosome is an actin-organizing centre. Nat Cell Biol. 2016; 18(1):65-75.

12. Patel H, Gordon MY. Abnormal centrosome-centriole cycle in chronic myeloid leukaemia? $\mathrm{Br} J$ Haematol. 2009;146(4):408-17.

13. Wang W, Chen L, Ding Y, Jin J, Liao K. Centrosome separation driven by actin-microfilaments during mitosis is mediated by centrosome-associated tyrosine-phosphorylated cortactin. J Cell Sci. 2008; 121(Pt 8):1334-43.

14. Birnboim HC, Doly J. A rapid alkaline extraction procedure for screening recombinant plasmid DNA. Nucleic Acids Res. 1979;7(6):1513-23.

15. Sauer ML, Kollars B, Geraets R, Sutton F. Sequential $\mathrm{CaCl} 2$, polyethylene glycol precipitation for RNase-free plasmid DNA isolation. Anal Biochem. 2008;380(2):310-4.

16. Mowiol mounting medium. Cold Spring Harb Protoc 2006; 2006(1): pdb.rec10255. 
17. Whittaker ET. XVIII-On the Functions which are represented by the Expansions of the InterpolationTheory. Proc R Soc Edinburgh 1915; 35:181-94.

18. Shannon $C E$. Communication In The Presence Of Noise. Proc IEEE 1998; 86(2): 447-57.

19. Schindelin J, Arganda-Carreras I, Frise E, Kaynig V, Longair M, Pietzsch T, Preibisch S, Rueden C, Saalfeld S, Schmid B, Tinevez JY, White DJ, Hartenstein V, Eliceiri K, Tomancak P, Cardona A. Fiji: an open-source platform for biological-image analysis. Nat Methods. 2012;9(7):676-82.

20. Bolte S, Cordelières FP. A guided tour into subcellular colocalization analysis in light microscopy. J Microsc. 2006;224(Pt 3):213-32.

21. Manders EMM, Verbeek FJ, Aten JA. Measurement of co-localization of objects in dual-colour confocal images. J Microsc 1993; 169(3): 375-82.

22. Sage D, Donati L, Soulez F, Fortun D, Schmit G, Seitz A, Guiet R, Vonesch C, Unser M. DeconvolutionLab2: An open-source software for deconvolution microscopy. Methods. 2017;115:28-41.

23. Dey N, Blanc-Feraud L, Zimmer C, Roux P, Kam Z, Olivo-Marin JC, Zerubia J. Richardson-Lucy algorithm with total variation regularization for $3 \mathrm{D}$ confocal microscope deconvolution. Microsc Res Tech. 2006;69(4):260-6.

24. Kirshner H, Aguet F, Sage D, Unser M. 3-D PSF fitting for fluorescence microscopy: implementation and localization application. J Microsc. 2013; 249(1):13-25.

25. Aigouy B, Mirouse V. ScientiFig: a tool to build publication-ready scientific figures. Nat Methods. 2013;10(11):1048.

26. Pihan GA, Wallace J, Zhou Y, Doxsey SJ. Centrosome abnormalities and chromosome instability occur together in pre-invasive carcinomas. Cancer Res. 2003;63(6):1398-404.

27. Nigg EA. Origins and consequences of centrosome aberrations in human cancers. Int $J$ Cancer. 2006; 119(12):2717-23.

28. Giehl M, Fabarius A, Frank O, Hochhaus A, Hafner $M$, Hehlmann $R$, Seifarth $W$. Centrosome aberrations in chronic myeloid leukemia correlate with stage of disease and chromosomal instability. Leukemia. 2005;19(7):1192-7.
29. Krueger EW, Orth JD, Cao H, McNiven MA. A dynamin-cortactin-Arp2/3 complex mediates actin reorganization in growth factor-stimulated cells. Mol Biol Cell. 2003;14(3):1085-96.

30. Gu C, Yaddanapudi S, Weins A, Osborn T, Reiser J, Pollak M, Hartwig J, Sever $S$. Direct dynamin-actin interactions regulate the actin cytoskeleton. EMBO J. 2010;29(21):3593-606.

31. Cao H, Weller S, Orth JD, Chen J, Huang B, Chen JL, Stamnes M, McNiven MA. Actin and Arf1dependent recruitment of a cortactin-dynamin complex to the Golgi regulates post-Golgi transport. Nat Cell Biol. 2005;7(5):483-92.

32. Chen L, Wang ZW, Zhu JW, Zhan X. Roles of cortactin, an actin polymerization mediator, in cell endocytosis. Acta Biochim Biophys Sin (Shanghai). 2006;38(2):95-103.

33. Zhu J, Zhou K, Hao JJ, Liu J, Smith N, Zhan X. Regulation of cortactin/dynamin interaction by actin polymerization during the fission of clathrin-coated pits. J Cell Sci. 2005;118(Pt 4):807-17.

34. Feit H, Slusarek L, Shelanski ML. Heterogeneity of tubulin subunits. Proc Natl Acad Sci US A. 1971;68(9):2028-31.

35. Khodjakov A, Rieder CL. The sudden recruitment of gamma-tubulin to the centrosome at the onset of mitosis and its dynamic exchange throughout the cell cycle, do not require microtubules. $J$ Cell Biol. 1999;146(3):585-96.

36. Raynaud-Messina B, Merdes A. Gamma-tubulin complexes and microtubule organization. Curr Opin Cell Biol. 2007;19(1):24-30.

\section{Домен PH білка BCR забезпечує колокалізацію повнорозмірного BCR з центросомою разом 3 кортактином для забезпечення актиноорганізуючої функції.}

\section{Д. С. Гур'янов, С. В. Антоненко, Г. Д. Телегєєв}

Хромосомна транслокація між 9 і 22 хромосомами призводить до злиття генів $b c r$ та $a b l$. Через різні точки розриву гена $b c r$ існують три форми химерних білків BCR-ABL - p230, p210 та p190. BCR-ABLp190 не має домену гомології Плекстрину (PH) BCR і асоціюється 3 гострим лімфобластним лейкозом. 3 іншого 
боку, BCR-ABL 210 має домен PH і виникає під час хронічного мієлобластного лейкозу. BCR-ABL може зв'язуватися з центросомами, які функціонують як регулюючий центр поділу клітини та формування веретена поділу під час мітозу. Кортактин, основною функцією якого є розгалуження актину, раніше був визначений за допомогою мас-спектрометрії одним із потенційних партнерів взаємодії домену PH BCR. Мета. Визначити, чи колокалізуються BCR та кортактин $з$ центросомами та можлива роль домену РН у такій колокалізації. Методи. Культивування клітин ссавців, імунофлуоресцентний аналіз, флуоресцентна мікроскопія живих клітин. Результати. У цій роботі ми показуємо, що як повнорозмірний білок BCR, так i домен РН можуть колокалізуватися з центросомою разом з кортактином у живих клітинах НЕК293Т. Ми також показали, що BCR колокалізується з $\gamma$-тубуліном та точками розгалуження актину у фіксованих клітинах K562. Використовуючи анти-ABL та анти-BCR антитіла, ми також показуємо, що колокалізація з центром розгалуження актину є типовою для BCR-ABL та BCR, але не для виключно ABL. Висновки. Домен PH BCR необхідний для колокалізації BCR або BCR-ABL 3 центросомою. Разом з кортактином BCR-ABL може впливати на функцію центросоми через дерегуляцію розгалуження актину або аномальне фосфорилювання, що може бути предметом подальших досліджень.

К л юч о в і с л о в а: BCR-ABL, центросома, кортактин, ХМЛ.

\section{Домен PH BCR обеспечивает колокализацию полноразмерного BCR с центросомой вместе с кортактином для обеспечения функции организации актина}

\section{Д. С. Гурьянов, С. В. Антоненко, Г. Д. Телегеев}

Хромосомная транслокация между 9 и 22 хромосомами приводит к слиянию генов $b c r$ и $a b l$. Из-за разных точек разрыва в гене bcr существуют три формы химерных белков BCR-ABL - p230, p210 и p190. BCR$\mathrm{ABL}^{\mathrm{p} 190}$ не имеет домена гомологии плекстрина (PH) BCR и связан с острым лимфобластным лейкозом. Напротив, BCR-ABL ${ }^{\mathrm{p} 210}$ имеет домен $\mathrm{PH}$ и возникает при хроническом миелобластном лейкозе. BCR-ABL может связываться с центросомами, которые действуют как регулирующий центр клеточного деления и образования веретена деления во время митоза. Кортактин, основной функцией которого является разветвление актина, ранее был идентифицирован масс-спектрометрией как один из потенциальных партнеров взаимодействия с PH доменом BCR. Цель. Определить, колокализуются ли BCR и кортактин с центросомами, и возможную роль домена РН в такой колокализации. Методы. Культивирование клеток млекопитающих, иммунофлуоресцентный анализ, флуоресцентная микроскопия живых клеток. Результаты. В настоящей работе мы показываем, что как полноразмерный белок BCR, так и домен $\mathrm{PH}$ могут колокализироваться с центросомой вместе с кортактином в живых клетках HЕК293Т. Мы также продемонстрировали, что BCR колокализуется с $\gamma$-тубулином и точками ветвления актина в фиксированных клетках К562. Используя антитела против ABL и против BCR, мы также показываем, что совместная локализация с центром ветвления актина типична для BCR-ABL и BCR, но не для одного лишь ABL. Выводы. Домен PH BCR необходим для колокализации BCR или BCR-ABL c центросомой. Вместе с кортактином BCR-ABL может влиять на функцию центросом за счет нарушения регуляции ветвления актина или аномального фосфорилирования, что может быть предметом дальнейших исследований.

Кл юч е в ы е сл ов а: BCR-ABL, центросома, кортактин, ХМЛ.

Received 03.09.2020 